\title{
Локализованные оптические фононы в нанопластинках ZnSe
}

\author{
Л.С. Басалаева ${ }^{1}$, Т.А. Дуда ${ }^{1}$, К.В. Аникин ${ }^{1}$, Б.М. Саиджонов ${ }^{2}$, Р.Б. Васильев ${ }^{2}$, А.Г. Милёхин ${ }^{1}$ \\ ${ }^{1}$ Институт физики полупроводников им. А.В. Ржанова СО РАН, Новосибирск, \\ 630090, пр. ак. Лаврентьева, 13 \\ ${ }^{2}$ Московский государственный университет им. М.В. Ломоносова, Москва, \\ 119991, Ленинские горы, 1 \\ тел:+7 (383) 330-8204, факс:+7 (383) 333-2771, эл.nочта: basalaeva@isp.nsc.ru
}

DOI 10.34077/RCSP2021-108

В последние годы возрос интерес к наноструктурам из II-VI полупроводников благодаря перспективам их применения в оптоэлектронике и фотовольтаике [1]. ZnSe - это прямозонный полупроводник, с шириной запрещенной зоны 2,7 эВ при комнатной температуре, обладает большой энергией связи экситона, считается перспективным для различных оптоэлектронных устройств, таких как синие лазерные диоды и фотодетекторы [2]. Более того, ZnSe не содержит токсичных элементов и является альтернативой хорошо исследованным халькогенидам кадмия. На настоящий момент сообщалось о синтезировании различных нанообъектов на основе ZnSe: наносфер, нанолистов (нанопластинок), наностержней, нанотрубок и др [3, 4]. Нанопластинки привлекают к себе особое внимание исследователей, т. к. имеют сверхмалую однородную толщину в несколько монослоев, латеральный размер в десятки нанометров и обладают узкими линиями поглощения и излучения и высоким квантовым выходом [5]. Однако оптические и колебательные свойства нанопластинок $\mathrm{ZnSe}$ изучены недостаточно. Актуальной остается задача определения зависимости фононного спектра нанопластинок $\mathrm{ZnSe}$ от их латеральных размеров и структуры, поскольку фононы определяют каналы рекомбинации возбужденных носителей заряда.

В данной работе исследовался фононный спектр нанопластинок ZnSe разной толщины, синтезированных методом коллоидной химии. Для определения структурных параметров нанопластинок $\mathrm{ZnSe}$ использовалась просвечивающая электронная микроскопия. Нанопластинки $\mathrm{ZnSe}$ наносились капанием на Si подложку, покрытую тонким слоем (100 нм) золота. Затем проводился термический отжиг полученных образцов при $\mathrm{T}=140^{\circ} \mathrm{C}$ для удаления органики. Для измерения ИК спектров использовался ИК Фурье спектрометр Vertex 80v. ИК измерения проводились при нормальном и наклонном $\left(\Theta \approx 75^{\circ}\right)$ падении. Измерение спектров КРС проводилось с помощью спектрометра Horiba XploRa Plus в геометрии обратного рассеяния при комнатной температуре, длины волн возбуждения составляли 532 и 638 нм.

КРС традиционно используется для изучения фононного спектра полупроводниковых структур [6]. В случае КРС нанопластинок $\mathrm{ZnSe}$ изучение спектров КРС затруднено, поскольку нанопластинки $\mathrm{ZnSe}$ оказались чрезвычайно подвержены процессам фотодеградации под действием лазерного излучения. Более того, в спектрах КРС проявляется интенсивная мода кристаллического селена на частотах, близких к частотам собственных колебаний $\mathrm{ZnSe}$. Оказалось, что наиболее информативна для изучения фононного спектра является ИК спектроскопия, для которой не характерно влияние ИК излучения на структуру материала. Кроме того, в спектрах КРС моды селеная запрещены правилами отбора.

В ИК спектрах отражения, регистрируемых при нормальном падении, наблюдались моды поперечных и поверхностных оптических фононов (ТО и SO моды, соответственно). При наклонном падении вследствие эффекта Берремана [7] наблюдались дополнительно продольные оптические (LO)моды. Показано, что при уменьшении толщины нанопластинок $\mathrm{ZnSe}$ наблюдается низкочастотный сдвиг фононных мод, обусловленный эффектом локализации фононов. По данным ИК спектроскопии определена толщина исследуемых нанопластинок, которая составила величину от 1 до 4 монослоёв.

Работа выполнена при поддержке РФФИ (грант 18-29-20066 мк).

\section{Лumepamypa}

[1] M. Afzaala, P. O'Brien // J. Mater. Chem. 2006. V.16. P.1597-1602.

[2] S-Z. Kang et al. // Ceramics International. 2014, V. 40. P.699-702.

[3] Q. Zhang et al. // Progress in Material Science. 2016. V.83. P.472-535.

[4] P. Reiss. // New J. Chem. 2007. V.31. P.1843-1852.

[5] Z. Chen et al. // Adv. Funct. Mater. 2014. V.24. P.295-302.

[6] V.M. Dzhagan et al. // Journal of Physics D: Applied Physics. 2018. V.51 P.503001

[7] D. W. Berreman //Phys. Rev. 1963. V.130. P. 2193 